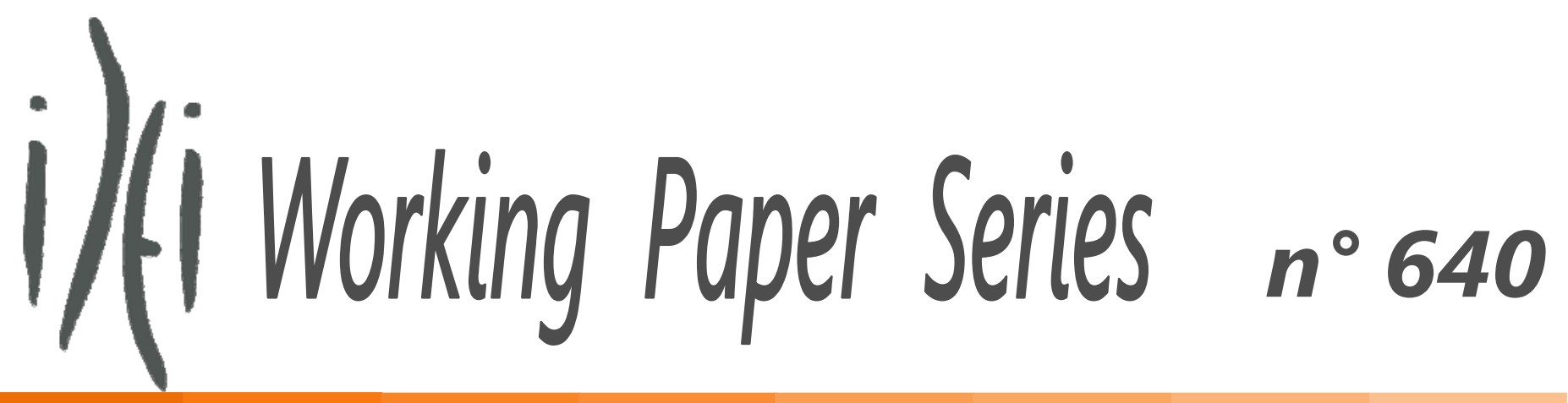

July, 2010

\title{
"Is the Level of Financial Sector Development a Key Determinant of Private Investment in the Power Sector?"
}

\author{
Lika BA, Farid GASMI and \\ Paul NOUMBA UM
}




\title{
Is the level of financial sector development a key determinant of private investment in the power sector?*
}

\author{
Lika BA \\ Ecole des Hautes Etudes en Sciences Sociales, Paris \\ nlikaba@hotmail.fr \\ Farid GASMI \\ Toulouse School of Economics (ARQADE \& IDEI) \\ Université Toulouse 1 Capitole \\ farid.gasmi@tse-fr.eu \\ Paul NOUMBA UM \\ The World Bank, Washington, DC \\ pnoumbaum@worldbank.org
}

JEL-codes: L33, L38, L94, L97, C23

Key words: Infrastructure sectors, Public-private partnership, Power sector, Financial development, Economic growth.

\footnotetext{
*We thank Luis Andres, Jon Stern, and Loïc Whitmore for having provided us with parts of the data used in this paper. The authors would like to thank Laszlo Lovei, Ritva Reinnika, Emmanuel Mbi, Shamshad Akhtar, Antonio Estache, James P. Bond, Gaetane Tracz, Douglas Pearce, Simon Bell, Jeff Delmon, Jose Luis Guasch, Marianne Fay and Tito Yepes. The findings, interpretations and conclusions expressed in this paper are entirely those of the authors. They do not represent the views of the International Bank for Reconstruction and Development/ World Bank and its affiliate organizations. The authors are responsible for any remaining errors.
} 


\section{Introduction}

In recent years, a host of developing countries have experienced robust economic growth but to sustain such growth prospects these countries need to significantly increase investment in infrastructure. ${ }^{1}$ To bridge the investment gap they currently face, developing countries need both to improve the quality of public spending in infrastructure as well as to attract more private capital. Rapid urbanization and economic growth, demographic trends, and climate change are all but some of the challenges that developing countries have to face and that call for an acceleration of public and private investments to rehabilitate, upgrade, and expand their infrastructures. Moreover, sustaining good quality of infrastructure service delivery requires a better composition of the infrastructure stock, a good level of maintenance, and an appropriate sequencing of institutional reforms across sectors including the financial sector.

Low or non-existent sovereign credit ratings and the absence of proper financial instruments to mitigate risks inherent to infrastructure projects are among the factors that limit private commitments in developing regions' infrastructure projects. ${ }^{2}$ After a sharp decline from relatively high levels in the mid-1990s, annual private investment in infrastructure in developing countries has stabilized in the 11-to-16 billion USD range since 2001 with a debt-equity distribution that varies across regions. For instance, while bonds have become an important tool for financing infrastructure investments in the Latin America and East Asia regions, representing, during the 1996-2004 period, 29\% and 14\% of infrastructure financing respectively, bond financing is nearly non-existent in the Middle East and North Africa region where about $98 \%$ of private investments in infrastructure has been in the form of loans from banks.

Because they mobilize lumpy investment and deliver future payoff in local currency, infrastructure projects financed with hard currency are exposed to currency devaluation and to the volatility of interest rates. Therefore, strengthening the capacity of local financial markets so they can extend debt and equity financing instruments denominated in local currency in competitive terms is crucial to

\footnotetext{
${ }^{1}$ Empirical work (Yepes, 2008) suggests that developing countries need to invest approximately 5 to 7 percent of their GDP in infrastructures to be able to maintain economic growth in the period 2008-2115 at their current average rate of 5 percent. For a survey on the relationship between infrastructure development and growth, see Straub (2008).

${ }^{2}$ The experiences of Cameroon, Nigeria, and Tanzania have indeed shown how macroeconomic, institutional, and financial reforms can increase longer-term local currency financing for banks, and therefore progressively increase local bank financing for infrastructure projects.
} 
accelerating private investment in infrastructure in developing countries. In the late 1980s-early 1990s, developing countries sought to develop their financial markets by implementing structural reforms including removing regulatory bottlenecks and rolling back the interventionist role of the state through privatization of commercial banks or by strengthening the independence of central banks. In parallel, project sponsors have also attempted to increase the use of local currency loans in closing the financing of infrastructure projects in developing countries. ${ }^{3}$ These efforts to develop appropriate local financial markets have however faced further difficulties due to the nature and profile of infrastructure projects (high economic stakes, long payback, and exposure to political interferences).

While the need for developing countries to foster investment in infrastructure sectors has been emphasized in the literature, the issue of these countries' limitations to attract private capital remains relatively weakly explored. This paper seeks to contribute to filling this void by testing that the level of economic and financial development of a country is a good "predictor" of its ability to attract private investment in infrastructure projects. We specify a regression model that we fit to a 19902007 annual data set on the power sector in 37 developing countries.

Our findings suggest that a country's level of economic development matters to private investors seeking to enter infrastructure sectors in developing countries. Similarly, we find empirical evidence that the level of development of a country financial sector, in particular the extent to which local capital markets are developed, is a key determinant of private investment in the power sector. As can be expected, quality of governance, and risk factors, such as exchange rate fluctuations, also influence private investors' decisions. In all our regressions, the existence of an autonomous energy sector regulator is found to significantly simulate private investment in power projects. These effects are significant even when we account for the interactions between economic growth and financial sector development.

The paper is organized as follows. The next section provides a review of the literature that discusses the role of infrastructure in development, its financing, and the determinants of private participation in infrastructure projects. Section 3 describes the data used, the main variables of interest, and briefly discusses some simple properties of the data. Section 4 presents the econometric approach used to

\footnotetext{
${ }^{3}$ Note, however, that these initiatives have only led to some local currency loans and bond issuances mainly concerned telecom projects.
} 
analyze the data. Sections 5 through 8 present the results of our econometric analysis. Section 9 concludes and the appendix provides some complementary material.

\section{Related literature}

The importance of infrastructure development for poverty reduction and long-run economic growth in low-income and developing countries started being highlighted in the 1990s, and this view has been since reinforced. The relationship between infrastructure development and economic growth has been characterized as one of a "virtuous circle" in the sense that a sustainable development in infrastructure is not possible without strong economic growth and growth is not possible without substantial improvements in the delivery of infrastructure services (The World Bank, 2006). ${ }^{4}$

As in most parts of the world, infrastructure services were traditionally provided by stated-owned vertically integrated monopolies in developing countries. ${ }^{5}$ This model became plagued by poor performance due to various factors including political interference, inefficient management, and under-investment. Under limited resources, the public sector alone in developing countries cannot ensure adequate infrastructure funding together with the operational activities necessary to effectively provide quality of service (Saidi, 2006). Consequently, existing infrastructures in developing countries need upgrading and modernization. This situation has made the financing of infrastructure projects even more challenging as demand for infrastructure services has substantially increased following population growth and large-scale urbanization.

To reduce the gap between infrastructure demand and supply in developing countries, partnerships between public and private sectors have been advocated. Public-Private Partnerships (PPPs) became one of the most popular financial mechanisms used to mobilize private capital for infrastructure financing. Local currency financing would have been preferred in most cases to avoid exposure to foreign exchange risk, whereas infrastructure projects with private participation are often financed

\footnotetext{
${ }^{4}$ It has been argued that infrastructure contributes to growth by enlarging markets, reducing trade barriers and economic risk of private investments, and increasing productivity, output, and employment (Prud'homme, 2004, Saidi, 2006). Infrastructure development contributes to poverty reduction by enhancing the poor's access to local and foreign markets and providing them with better information on market opportunities and ways to improve their standards of living (Jerome, 2008).

${ }^{5}$ The public good nature of infrastructure services, the existence of externalities, and the incompleteness of markets are the main market failures invoked to justify state intervention (Calitz and Fourie, 2007). However, infrastructure services are increasingly becoming rival and excludable goods, therefore questioning the necessity of public intervention.
} 
with a mix of hard currency denominated equity and non-recourse debt. ${ }^{6}$

Partnerships between the public and private sectors were viewed as mechanisms that would allow gathering and channeling the needed amount of resources to sustain growth and alleviate poverty in developing countries (The World Bank, 2006). Consequently, many developing countries undertook large-scale reforms of their infrastructure sectors in the late 1980s-early 1990s with the goal of promoting competition through liberalization, improving regulation of the sectors, and involving private and foreign actors in infrastructure ownership, management, operations, and service provision. Despite these reforms, developing countries still have to enhance private sector involvement in infrastructure financing through the implementation of coordinated reforms in the financial sector. ${ }^{7}$

Stimulating private participation in the provision of public services is challenging, and even more so for low-income and developing countries. Projects design, risks identification and allocation, the availability of risk mitigation financial instruments, the institutional and regulatory framework, and the local financial markets' depth and composition are all but some of the key determinants of a country's ability to successfully mobilize private investment (Calitz and Fourie, 2007). ${ }^{8}$ It is often argued that the difficulties of developing countries in attracting private investors in infrastructure sectors are essentially due to their poor or non-existent sovereign creditworthiness which partly can be explained by low income levels leading to low investor confidence in long-term policies, under-

\footnotetext{
${ }^{6}$ The borrower of a non-recourse debt is typically a special-purpose entity (PPP) created to own an infrastructure project. Investors (shareholders) that own this entity have generally no responsibility to repay the debt used to finance the specialpurpose entity. Shareholders often finance $20 \%$ of the project (in equity) and the remaining $80 \%$ is usually financed through a bank loan guaranteed by the government (through the PPP). If borrowers fail to reimburse, the only recourse for the bank is to "step in" the entity's management if the failure is due to a managerial problem. Collective bond issuances are also often used. They consist of a credible intermediary, such as the central government, which establishes a Bond Bank that collects all the borrowing needs of municipalities and issues a single class of bond backed up by a diversified pool of loans. Platz (2009) argues that a particular attention should be paid to sub-sovereign bonds, essentially issued in local currency, as a source of infrastructure financing instrument as they "... generally target domestic capital market investors who are more familiar with the local governments than international creditors ...".

${ }^{7}$ Between 1997 and 2004, developing countries received only a small share of private investment. Africa attracted less non-recourse debt than other regions and has been less successful in raising financing through bond issuance. Moreover, most of the bond financing in Africa during this period was for South-African projects through local currency issues in the local capital markets (Sheppard et al. 2006).

${ }^{8}$ The World Bank (2006) has highlighted that the susceptibility of projects to governance, corruption, and political interference may alter private investment and advocated the need for governments to implement anti-corruption instruments and improve governance and rule of law, including investors' protection. Jerome (2008) underlines the importance of institutional and fiscal reforms. Although the depth and composition of local capital markets significantly affects their ability to mobilize capital, their actual ability to provide infrastructure financing depends on other factors, including the size of the domestic economy, the level of per capita income, macroeconomic stability, and the development of contractual savings institutions such as pension funds and life insurance (Sheppard, 2006).
} 
developed financial markets which do not offer enough capital and proper financial instruments, and high economic risk of infrastructure projects in these countries (Sheppard et al. 2006, Saidi, 2006, Jerome, 2008). All these factors alter private investors' confidence and therefore their investment decisions. ${ }^{9}$

As indicated earlier, infrastructure projects are preferably financed with a combination of local currency bonds and non-recourse debt. The domestic financial sector's depth and composition are therefore key determinants of a country's attractiveness for private investors. ${ }^{10}$ As infrastructure projects tend to be riskier than other sectors' projects, due to their longer payback and build-out periods and their exposure to political and regulatory risks, proper risk mitigating instruments are needed to improve investors’ confidence.

Developing and low-income countries are characterized by under-developed financial markets which essentially offer short-term local currency financing. Moreover, these markets often involve only a small number of players therefore reducing competition, distorting yields, and ultimately leading to high transaction costs (Platz, 2009). ${ }^{11}$

In recent years, commercial banks in developing countries have gained increased exposure to nonrecourse project financing in loan clubs or syndications led by major international banks. But, due to their difficulties to mobilize long-term finance, their overall ability to extend long-term loans in local currency to infrastructure PPP projects is significantly impeded (Sheppard, 2006). ${ }^{12}$ Furthermore, in most developing countries’ bond and secondary markets are embryonic or non-existent, and cannot therefore offer financial and risk mitigating instruments required for infrastructure projects (Gupta et al., 2001). While many developing countries have implemented structural reforms to further deepen their financial and capital markets since the mid-late 1990s, their financial sectors have not yet

\footnotetext{
${ }^{9}$ For instance, only 16 of 48 African countries have foreign currency debt ratings and only 4 of these 16 have ratings that give relatively broad access to financial markets (BB- or higher). These 4 countries represent $43 \%$ of regional GNI (dominated by South Africa) while this share represents more than two third of regional GNI in other developing regions. ${ }^{10}$ The OECD (2006) emphasizes the key role of financial markets development in promoting investment in infrastructure in the medium term.

${ }^{11}$ South Africa is an exception in Sub-Saharan Africa with a relatively well developed financial system capable of providing long-term local currency funding for infrastructure projects. Moreover, "... the government is a potential borrower of good standing, domestically and internationally, and has a significant borrowing capacity. Consequently, public-private partnerships have steadily developed in South Africa during the past 20 years." (Calitz and Fourie, 2007).

${ }^{12}$ Financial intermediaries facilitate transactions, allocate capital, and collect savings. Therefore, an under-developed financial system may prevent households accessing banks and other institutions to deposit their savings, which could be used for infrastructure financing. The most prominent low- and middle- income countries with domestic banks that are
} 
reached a level of development required to catalyze the development of private investment in infrastructure.

Some empirical studies have investigated the determinants of private investment in developing countries, but most of them consider private flows to the economy as a whole and not to specific infrastructure sectors. Moreover, to our knowledge, very few empirical analyses have investigated the attractiveness of a country’s overall economic development level or financial development level to private investors in developing countries.

Pargal (2003) examines the effects of the regulatory framework on private investment in infrastructure in nine Latin American countries from 1980 to 1998 and finds that the investment regime's liberalization and the existence of independent regulatory agencies are the most significant institutional determinant of private investment. Ouattara (2004) investigates the long-run determinants of private investment in Senegal from 1970 to 2000 and reaches the conclusion that public investment, GDP per capita, and foreign aid positively influence private investment. In contrast, credit to the private sector and terms of trade surprisingly tend to hinder private investment in Senegal. Likewise, Zerfu (2001) finds that GDP, its growth rate, and public investment in infrastructure significantly foster private investment in Ethiopia while lack of macroeconomic stability tend to negatively affect investment.

Examining the determinants of infrastructure private investment in 61 developing countries over the period 1970-2003, Kinda (2008) also finds a significant positive effect of economic growth, physical infrastructure, and level of development of the financial sector, in particular, credit granted to the private sector by the banking sector. He also finds out, as in previous studies, that private investment is negatively influenced by macroeconomic and political instability. For the case of Ghana during the period 1970-1992, Asante (2000) finds that public investment, lagged private investment, and the growth of real credit to the private sector are key determinants of private investment. However, the author finds that the growth rate of GDP negatively influences private investment and so does macroeconomic and political instability.

\section{The data}


To investigate the influence that a country's level of economic and financial sector development level on private investment in the power sector in developing countries, we collected data on the 37 developing countries in Latin America and Caribbean, Asia, Middle East and North Africa, and SubSaharan Africa shown in Table 1 below. ${ }^{13}$ We note that 31 of these countries are middle income countries (MIC), meaning that they have relatively high growth rates and active financial sectors, enough to allow us to capture any potential effect of economic growth and financial sector development on private investment. In additional, autonomous energy sector regulatory authorities have been created in most of these countries during the period covered by our sample.

Table 2 below exhibits the list of variables on which data have been collected. More detailed information on these variables is given in Table A1 of the appendix. Here, we synthesize the main features of the variables. The dependent variable "Private capital in energy sector," is labeled privinvt. This variable represents the total amount, in millions of 2005 USD, of private investments in power projects undertaken in a given country during a given year. ${ }^{14}$ The independent variables that will draw much of our attention are regrouped under the labels "Economic development" and "Financial sector development." Overall economic development is represented by the variable growth, the growth rate of GDP per capita while the variable findev is used to represent the level of development of a country's financial sector. We also distinguish banking and capital market operations by using variables labelled bsdev and cmdev that reflect the development level of these respective (sub-) sectors.

The levels of financial sector development findev, bsdev, and cmdev are variables that are calculated as the first principal components of variables that represent the development level of the banking and the capital market sectors. For the banking sector we use the variables $C B A, D M B A$, and $C B P C$. Expressed as fractions of GDP, these variables represent, respectively, total assets held by the Central Bank, total assets held by domestic financial institutions, and total loans granted by commercial banks to domestic corporate and households. ${ }^{15}$ As to the capital market, we use the variables SMC, TVT, and SMT. The variables SMC and TVT are also expressed as ratios to GDP and represent, respectively, stock market capitalization and value of shares traded on the stock market. These variables are meant to measure the size of the capital market and its liquidity respectively. The variable SMT is a market turnover variable that is meant to assess the stock market's efficiency. For a

\footnotetext{
${ }^{13}$ A country is considered as lower middle income when its 2008 GNI per capita is between USD 976 and USD 3,855, a higher middle income country when its 2008 GNI per capita is between USD 3,856 and USD 11,905, and as a low income country when its GNI per capita is equal to USD 975 or less.

${ }^{14}$ No distinction between local and foreign private investment is made in this paper.
} 
given year, it is calculated as the ratio of the total value of shares traded to the average market capitalization.

Table 1

Sample countries

\begin{tabular}{|c|c|c|}
\hline Country & World Bank Region & World Bank income group \\
\hline Argentina & Latin America \& Caribbean & Upper middle income \\
\hline Bangladesh & South Asia & Low income \\
\hline Bolivia & Latin America \& Caribbean & Lower middle income \\
\hline Brazil & Latin America \& Caribbean & Upper middle income \\
\hline Cameroon & Sub-Saharan Africa & Lower middle income \\
\hline Chile & Latin America \& Caribbean & Upper middle income \\
\hline China & East Asia \& Pacific & Lower middle income \\
\hline Colombia & Latin America \& Caribbean & Lower middle income \\
\hline Costa Rica & Latin America \& Caribbean & Upper middle income \\
\hline Cote d'Ivoire & Sub-Saharan Africa & Low income \\
\hline Ecuador & Latin America \& Caribbean & Lower middle income \\
\hline Egypt & Middle East \& North Africa & Lower middle income \\
\hline El Salvador & Latin America \& Caribbean & Lower middle income \\
\hline India & South Asia & Lower middle income \\
\hline Indonesia & East Asia \& Pacific & Lower middle income \\
\hline Jamaica & Latin America \& Caribbean & Upper middle income \\
\hline Malaysia & East Asia and Pacific & Upper middle income \\
\hline Mexico & Latin America \& Caribbean & Upper middle income \\
\hline Moldova & Europe and Central Asia & Lower middle income \\
\hline Morocco & Middle East \& North Africa & Lower middle income \\
\hline Nigeria & Sub-Saharan Africa & Low income \\
\hline Panama & Latin America \& Caribbean & Upper middle income \\
\hline Paraguay & Latin America \& Caribbean & Lower middle income \\
\hline Peru & Latin America \& Caribbean & Lower middle income \\
\hline Philippines & East Asia and Pacific & Lower middle income \\
\hline South Africa & Sub-Saharan Africa & Upper middle income \\
\hline Sri Lanka & South Asia & Lower middle income \\
\hline Syria & Middle East \& North Africa & Lower middle income \\
\hline Thailand & East Asia and Pacific & Lower middle income \\
\hline Tunisia & Middle East \& North Africa & Lower middle income \\
\hline Turkey & Europe \& Central Asia & Upper middle income \\
\hline Ukraine & Europe \& Central Asia & Lower middle income \\
\hline Uruguay & Latin America \& Caribbean & Upper middle income \\
\hline Venezuela & Latin America \& Caribbean & Upper middle income \\
\hline Yemen & Middle East \& North Africa & Low income \\
\hline
\end{tabular}

${ }^{15}$ The variable $D M B A$ is meant to capture the depth of the banking sector. 
Zambia

Zimbabwe
Sub-Saharan Africa

Sub-Saharan Africa
Low income

Low income

In addition to these variables, we use some variables of the quality of a country's institutions, the level of risk, and the structure of regulation. A first group of variables, under the label "Institutional quality and risk," is meant to represent the degree of corruption of the country's political system (corruption), the ability of the country's government to commit to its announced economic program (govtstability), the extent of the legal system's impartiality and the observance of the law (lawandorder), the overall quality of the regulatory governance (regquality), the country's level of political and economic risk (countryrisk), and its exchange rate risk (exchraterisk). Finally, we account for the way "Energy sector regulation" is structured through the use of a variable (indepreg) that informs us on the existence of an autonomous energy/electricity sector regulator.

Table 3 gives some descriptive statistics on the variables. Developing countries attracted around USD 575 million on average between 1990 and 2007. The high standard deviation of private investment suggests that the latter has varied much across countries and years. The average growth rate of GDP per capita is $1.84 \%$ and the high standard deviation of this variable suggests that the countries in our sample have experienced quite different level of overall economic development. As to countries' financial sector development, by scrutinizing the different dimensions of the financial sector, we see that there is enough variability in the variables that represent them, yet somewhat than the one representing overall economic development.

Simple correlation coefficients between the variable representing private investment in energy projects, privinvt, and the main explanatory variables are presented in Table 4. These coefficients show that private investment is positively correlated with all variables, the higher correlation being with financial sector development, in particular, capital markets' development. The existence of an autonomous regulator and the country's overall quality of governance are also variables that are noticeably (positively) correlated with private investment. While these correlations give some useful preliminary indications on the sign and the magnitude of the relationships between our variables of interest, the next step in the analysis is to further explore these relationships through an econometric test. To this end, we use dynamic panel regression models and estimate them by applying ArellanoBover (1995) and Blundell-Bond (1998) System Generalized Method of Moments (SYS-GMM) 
estimation method.

Table 2

Variables and designation

\begin{tabular}{ll}
\hline Variable & Designation \\
\hline $\begin{array}{c}\text { Private capital in energy sector } \\
\text { privinvt }\end{array}$ & Private investment in energy projects
\end{tabular}

Economic development

growth Growth rate of GDP per capita

Financial development

$\begin{array}{ll}\text { findev } & \text { Overall financial development variable } \\ \text { bsdev } & \text { Banking sector development variable } \\ \text { cmdev } & \text { Capital markets development variable }\end{array}$

Institutional quality and risk

corruption Corruption index

govtstability Government stability variable

lawandorder Law and order variable

regquality Index of regulatory governance quality

countryrisk Country risk index

exchraterisk Exchange rate risk index

Energy sector regulation

indepreg Separated regulatory authority variable

Table 3

Summary statistics

\begin{tabular}{lcccccc}
\hline \hline Variable & Obs. & Mean & Std. Dev. & Min. & Max. & Median \\
\hline privinvt & 497 & 574.62 & 1430.47 & 0 & 13910 & 0 \\
growth & 666 & 1.84 & 4.88 & -30.86 & 16.15 & 2.49 \\
findev & 472 & $-3.25 \mathrm{E}-09$ & 1.78 & -3.72 & 3.61 & -0.54 \\
bsdev & 571 & $-3.21 \mathrm{E}-09$ & 1.39 & -2.70 & 2.60 & -0.02 \\
cmdev & 536 & $-3.71 \mathrm{E}-09$ & 1.53 & -2.99 & 2.88 & 0.09 \\
CBA & 575 & 0.09 & 0.11 & 0.00 & 0.71 & 0.06 \\
DMBA & 584 & 0.41 & 0.28 & 0.07 & 1.73 & 0.35 \\
CBPC & 586 & 0.35 & 0.30 & 0.04 & 1.66 & 0.25 \\
SMC & 545 & 0.34 & 0.44 & 0.00 & 2.82 & 0.19 \\
SMT & 546 & 0.28 & 0.42 & 0.00 & 3.44 & 0.12 \\
TVT & 549 & 0.12 & 0.26 & 0.00 & 2.37 & 0.03 \\
corruption & 650 & 3 & 1 & 0 & 5 & 3 \\
\hline
\end{tabular}




\begin{tabular}{lcccccc}
\hline govtstability & 650 & 8 & 2 & 1 & 12 & 8 \\
lawandorder & 650 & 3 & 1 & 0 & 6 & 3 \\
regquality & 333 & -0.15 & 0.65 & -2.37 & 1.48 & -0.07 \\
countryrisk & 650 & 65 & 8 & 35 & 82 & 67 \\
exchraterisk & 650 & 8 & 2 & 0 & 10 & 8 \\
indepreg & 666 & 0.39 & 0.49 & 0 & 1 & 0 \\
\hline
\end{tabular}

Table 4*

Correlation coefficients

\begin{tabular}{lc}
\hline \hline Variable & Correlation coefficient \\
\hline growth & 0.033 \\
findev & 0.249 \\
bsdev & 0.089 \\
cmdev & 0.312 \\
corruption & 0.011 \\
govtstability & 0.068 \\
lawandorder & 0.066 \\
regquality & 0.181 \\
countryrisk & 0.173 \\
exchraterisk & 0.044 \\
indepreg & 0.200 \\
*This table gives the correlation coefficients between the variable of primary interest, privinvt, and the \\
variables shown in the first column.
\end{tabular}

\section{Econometric specification}

To evaluate whether or not a country's level of economic and financial sector development is a key determinant of private investment in the power sector in developing countries, we run a set of regressions with the level of annual private investment in energy projects as the dependent variable. In addition to the independent variables of main interest, namely, those used to proxy the levels of economic and financial sector development, the set of right-hand variables of these regressions comprises variables that capture some important features such the country's institutional and regulatory environment. ${ }^{16}$ Thus, these regressions provide us with a framework for empirically testing the hypothesis that the level of economic and financial sector development is a key driver of private investment in developing countries' infrastructure projects while controlling for these other features of a country's economy.

Given that our data are in a pooled time-series cross-sectional form, we specify dynamic econometric models and estimate them using the one-step (robust) System Generalized Method of Moments

${ }^{16}$ Of particular interest to us is the role that the creation of an autonomous regulator and the country's overall quality of 
(SYS-GMM) developed by Arellano-Bover (1995) and Blundell-Bond (1998) for dynamic panel models. ${ }^{17}$ It is well known that in such a modeling framework (see Beck and Katz, 2004) "... with a non-stationary dependent variable, the dispersion of the value of the coefficient in an AR (1) process found with different asymptotically equivalent methods often exceeds its standard errors." We therefore test whether the dependent variable was stationary. ${ }^{18}$

Since the moment conditions used to estimate the models are valid only if there is no serial correlation in the idiosyncratic errors, an Arellano-Bond test of the hypothesis of no autocorrelation in the first-differenced errors and a Hansen-J test of the null hypothesis that over-identifying restrictions are valid are also performed for each model. ${ }^{19}$ The Dif-Hansen statistic allows us to test that additional SYS-GMM moment conditions used are valid. ${ }^{20}$ To avoid over-fitting bias, i.e., using too many moment conditions, we made sure that the number of instruments used (the lags of the dependent variable) is not "too high" relative to the number of observations. ${ }^{21}$ The joint significance of the explanatory variables is testing with a Fisher test and endogeneity of the main variables of interest is addressed by means of a Hausman test.

Our econometric analysis of the impact of the level of economic and financial sector development of a country on its ability to attract private investment is built on a stepwise procedure that is organized around two main objectives. A first objective is to examine whether overall economic development and financial sector development levels are indeed key determinants of private investment. A second objective is to further explore the impact of the level of financial sector development, if found to be significant, by decomposing it into its banking sector and financial market components.

The first objective is tackled by means of regressions of the following general form:

$$
\text { privinvt }_{i t}=\alpha_{1} \text { privinvt }_{i t-1}+\alpha_{2} \text { growth }_{i t}+\alpha_{3} \text { findev }_{i t}+\mathrm{x}^{\prime} \beta+\varepsilon_{i t}
$$

\footnotetext{
governance have played in building commitment of the private sector to fund energy projects.

${ }^{17}$ The general structure of this estimation method is sketched in the appendix.

${ }^{18}$ This test showed that the dependent variable does not contain a unit root (details are available from the authors upon request).

${ }^{19}$ While first-order autocorrelation is expected, rejecting the hypothesis of no serial correlation at higher orders implies that instruments are not valid. Note that Hansen-J test results are robust but can be weakened by the use of too many instruments.

${ }^{20}$ With the estimation method used, however, Dif-Sargan test is not robust. We therefore present Dif-Hansen results instead.
} 
where $i=1,2, \ldots, 37 ; t=1,2, \ldots, 18$ are indices that refer to the country and the year respectively, the variables privinvt, growth, and findev are as defined in the previous section, $\alpha_{i}, i=1,2,3$ are the associated coefficients, $\mathrm{x}$ is a vector of control variables that are shown in Table 2 under the labels "Institutional quality and risk" and "Energy sector regulation," $\beta$ is the vector of coefficients associated with these control variables, and $\varepsilon$ is the error term.

To achieve the second objective, which is to further refine the analysis of the level of the financial sector development effect on volume of private investment in the power sector, we disaggregate the measure of the financial sector development level into its banking and capital market parts. Hence, we use the following general equation:

$$
\text { privinvt }_{i t}=\alpha_{1} \text { privinvt }_{i t-1}+\alpha_{2} \text { growth }_{i t}+\alpha_{3} \text { bsdev }_{i t}+\alpha_{3} \text { cmdev }_{i t}+\mathrm{x}^{\prime} \beta+\varepsilon_{i t}
$$

where bsdev and cmdev are as defined in section 3 above.

\section{The effect of the overall economic development level on private investment in the power sector}

Tables 5-12 below give the SYS-GMM parameter estimates of a set of regressions derived from equation (4). ${ }^{22}$ Part from the parameter estimates, the tables also report the number of observations actually used to estimate each model, Fisher F statistic testing the joint significance of the independent variables, Arellano-Bond first and second autocorrelation coefficients of the firstdifferenced residuals, the Hansen J statistic for testing the validity of instruments, and the DifHansen statistic allowing testing the validity of the additional SYS-GMM moment conditions. ${ }^{23}$

The analysis that led to Tables 5-7 focuses on the level of overall economic development as a factor that attracts private investors into the energy sector. From Table 5, we see that with a simple dynamic model having growth of GDP per capita as the sole explanatory variable, besides previous year volume of private investment, we obtain coefficients that are significant at the $5 \%$ level. $^{24}$ This

\footnotetext{
21 The number of lags was limited to 6 .

${ }^{22}$ For notational simplicity the first-difference operator is omitted in the tables. Moreover, we indicate by *, **, and $* * *$ respectively significance at the $20 \%, 10 \%$, and $5 \%$.

${ }^{23}$ We also report Arellano-Bond third autocorrelation coefficients when relevant.

${ }^{24}$ Second-order autocorrelation is rejected in most of the models and variables lagged two or more periods are used as instruments. Furthermore, the $\mathrm{J}$ statistic does not reject the validity of instruments in all models and the Dif-Hansen
} 
confirms both the presence of a dynamic structure in the flow of private electricity projects funding and that overall economic development is a signal that is positively interpreted by private investors.

Table 5

SYS-GMM parameter estimates

\begin{tabular}{ccc}
\hline \hline Variable & Coefficient & Std error \\
\hline lag(privinvt) & $.6782351^{* * *}$ & .0481902 \\
growth & $.9667271^{* * *}$ & .289288 \\
\hline Obs. & 436 & \\
Fisher test & $\mathrm{F}(2,34)=124.83^{* * *}$ & \\
Arellano Bond test - Order 1 & $-2.67 * * *$ & \\
Arellano Bond test - Order 2 & 0.78 & \\
Hansen-J & chi2(58) $=29.83$ & \\
Dif-Hansen & chi2(30) $=5.69$ & \\
\hline
\end{tabular}

While the results exhibited in Table 5 are interesting by themselves as they confirm our intuition, there are at least two reasons that suggest extending the underlying model. First, the model is so parsimonious that the variable omission bias is a real threat. Second, as discussed earlier in the paper, besides uncovering the attractiveness of the economic and financial sector development of a country to potential private investors, we are also interested in the effect of the political and institutional environment of the country on private investment. Tables 6 and 7 below present results obtained when we estimate the economic growth effect while first controlling for the quality of governance in the whole economy (Table 6) and then for both that quality and for the existence of an independent regulatory authority in the energy sector (Table 7$).{ }^{25}$ We see that the coefficients of these control variables have the expected sign and are significant, and that the overall economic development as measured remain highly is significant even when we adjust for the institutional environment.

Table 6

SYS-GMM parameter estimates

\begin{tabular}{ccc}
\hline \hline Variable & Coefficient & Std error \\
\hline lag(privinvt) & $.6880732^{* * *}$ & .1113495 \\
growth & $.6551585^{* * *}$ & .1988469 \\
regquality & $121.1382^{* *}$ & 68.03486 \\
\hline Obs. & 248 & \\
Fisher test & $\mathrm{F}(3,33)=21.39^{* * *}$ & \\
Arellano Bond test - Order 1 & $-2.20^{* * *}$ & \\
\hline
\end{tabular}

statistic validates the additional SYS-GMM moment conditions. Finally, Hausman test results show that economic and financial development variables are exogenous in most of the models. In the few cases where this is not the case, the variables of interest are therefore instrumented. For a treatment of the endogeneity of institutional variables in infrastructure sectors, see Gasmi et al. (2009).

${ }^{25}$ Note that we systematically incorporate all the control variables in the models estimated, but we only keep and present those with reasonable goodness-of-fit. 


\begin{tabular}{cc}
\hline Arellano Bond test - Order 2 & $2.22^{* * *}$ \\
Arellano Bond test - Order 3 & -1.26 \\
Hansen-J & chi2(13) $=8.95$ \\
Dif-Hansen & chi2(9) $=4.29$ \\
\hline
\end{tabular}

Table 7

SYS-GMM parameter estimates

\begin{tabular}{ccc}
\hline \hline Variable & Coefficient & Std error \\
\hline lag(privinvt) & $.6655032^{* * *}$ & .1001062 \\
growth & $.2784228^{* *}$ & .1496112 \\
regquality & $100.8325^{*}$ & 74.44351 \\
indepreg & $354.6202^{* * *}$ & 142.9526 \\
\hline Obs. & 248 & \\
Fisher test & $\mathrm{F}(4,33)=20.17^{* * *}$ & \\
Arellano Bond test - Order 1 & $-2.22^{* * *}$ & \\
Arellano Bond test - Order 2 & $2.25^{* * *}$ & \\
Arellano Bond test - Order 3 & -1.13 & \\
Hansen-J & chi2(13) $=11.08$ & \\
Dif-Hansen & chi2(9) $=5.95$ & \\
\hline
\end{tabular}

\section{The effect of the financial sector development level on private investment in the power sector}

Let us now examine the financial sector effect. Tables 8-10 below present the results of an analysis that follows the same approach as for the case of the overall economic development level discussed above. We first focus on the level of financial sector development and subsequently add risk and institutional quality variables. We then start from the estimation of a "naive" dynamic model in which we assume that the level of development of the financial sector, findev, is the only factor that affects private investment (Table 8). We then introduce control variables to adjust for the effect of financial risk (Table 9) and both the effects of financial risk and institutional environment (Table 10). Here again, the results supports the proposition that the state of development of the financial sector matters for private investors.

As can be seen from Table 8, financial sector development significantly influences private investment in developing countries' power projects as findev is found to be significantly and positively related to private investment. We next examine the importance of the institutional environment and risk factors for private investors when considering the level of development of developing countries’ financial sector. Table 9 confirms that financial sector development positively and significantly affects private investment, and also emphasizes that among all institutional and risk measures considered in this study, exchange rate risk is key determinant to private investment in the 
power sector. Our findings therefore suggest that, when assessing the financial sector's development of a country, private investors also take the country's level of exchange rate risk into account. Hence, the latter appears to be the most important risk factor that can hinder the private sector's participation in power projects' funding.

\section{Table 8}

SYS-GMM parameter estimates

\begin{tabular}{ccc}
\hline \hline Variable & Coefficient & Std error \\
\hline lag(privinvt) & $.6762986^{* * *}$ & .0525712 \\
findev & $231.7872^{* * *}$ & 103.6243 \\
\hline Obs. & 307 & \\
Fisher test & $\mathrm{F}(2,28)=86.86^{* * *}$ & \\
Arellano Bond test - Order 1 & $-2.31^{* * *}$ & \\
Arellano Bond test - Order 2 & -0.07 & \\
Hansen-J & chi2(58) $=26.49$ & \\
Dif-Hansen & chi2(30) $=4.09$ & \\
\hline
\end{tabular}

\section{Table 9}

SYS-GMM parameter estimates

\begin{tabular}{ccc}
\hline \hline Variable & Coefficient & Std error \\
\hline lag(privinvt) & $.6564802^{* * *}$ & .0476423 \\
findev & $109.5548^{* *}$ & 59.46446 \\
exchraterisk & $28.64363^{* * *}$ & 8.754116 \\
\hline Obs. & 306 & \\
Fisher test & $\mathrm{F}(3,28)=90.35^{* * *}$ & \\
Arellano Bond test - Order 1 & $-2.35^{* * *}$ & \\
Arellano Bond test - Order 2 & -0.03 & \\
Hansen-J & chi2(29) $=23.29$ & \\
Dif-Hansen & chi2(15) $=7.05$ & \\
\hline
\end{tabular}

When investigating whether the existence of an autonomous energy regulator matters for private investors by adding the variable indepreg as an independent variable in the previous model, our results (Table 10) show that the effects of findev and exchraterisk on private investment are not altered as both variables still significantly impact private investment in power projects. Our findings also highlight that the existence of an autonomous energy regulator matters for private investment as the variable indepreg significantly increases the volume of private investment. It therefore appears that developing countries' domestic financial sector's development, their level of exchange rate risk and their regulatory framework, more specifically, the existence of an autonomous energy regulator, are all but important determinants of private investment in these countries' energy projects. 
Table 10

SYS-GMM parameter estimates

\begin{tabular}{ccc}
\hline \hline Variable & Coefficient & Std error \\
\hline lag(privinvt) & $.54575^{* * *}$ & .0912674 \\
findev & $122.0128^{* *}$ & 71.0817 \\
exchraterisk & $18.28363^{* * *}$ & 8.137896 \\
indepreg & $364.9427^{*}$ & 257.483 \\
\hline Obs. & 306 & \\
Fisher test & $\mathrm{F}(4,28)=23.08^{* * *}$ & \\
Arellano Bond test - Order 1 & $-2.45^{* * *}$ & \\
Arellano Bond test - Order 2 & -0.07 & \\
Hansen-J & chi2(23) $=24.34$ & \\
Dif-Hansen & chi2(12) $=12.44$ &
\end{tabular}

\section{Putting together the effects of the overall economic and financial sector development levels on investment in the power sector}

The results discussed so far indicate that economic growth and financial development are both key determinants of the volume of private investment in developing countries' energy projects. More specifically, our analysis has shown that higher economic and financial development is associated to higher private investment. We therefore express this latter as a function of both variables as described by equation (1) to check whether these effects still hold when the potential interactions between these variables are taken into account by applying the same methodology as in the previous sections. Tables 11 and 12 present our empirical results.

From Table 11 we see that both economic growth and financial sector development indeed remain positively and significantly related to the level of private investment in energy projects, thereby confirming our previous conclusion that these variables are key determinants of private involvement in infrastructure projects' financing. When the institutional and risk variables are added to the model, none of them appear to significantly affect private investment. We therefore use the model growth and findev only to investigate the consistency of the importance of the existence of an independent energy sector regulator for private investors.

Does the existence of an autonomous regulator still matter? We investigate this question by adding 
indepreg as an independent variable in the previous model. We can see from our findings summarized in Table 12 that economic growth and the overall financial sector's development still positively and significantly affect the volume of private investment. Moreover, the existence of an independent regulator also appears to significantly help improving private investors' participation in energy projects' funding, which is consistent with our previous findings.

Table 11

SYS-GMM parameter estimates

\begin{tabular}{ccc}
\hline \hline Variable & Coefficient & Std error \\
\hline lag(privinvt) & $.6756518^{* * *}$ & .0402636 \\
growth & $.5322045^{* *}$ & .2874486 \\
findev & $99.72341^{* *}$ & 57.81029 \\
\hline Obs. & 307 & \\
Fisher test & $\mathrm{F}(3,28)=94.67^{* * *}$ & \\
Arellano Bond test - Order 1 & $-2.38^{* * *}$ & \\
Arellano Bond test - Order 2 & 0.05 & \\
Hansen-J & chi2(29) $=24.52$ & \\
Dif-Hansen & chi2(15) $=12.20$ & \\
\hline
\end{tabular}

Table 12

SYS-GMM parameter estimates

\begin{tabular}{ccc}
\hline \hline Variable & Coefficeint & Std error \\
\hline lag(privinvt) & $.6449181^{* * *}$ & .0806958 \\
growth & $.3440047^{*}$ & .239676 \\
findev & $96.74427^{* *}$ & 56.93634 \\
indepreg & $293.5705^{*}$ & 189.4488 \\
\hline Obs. & 307 & \\
Fisher test & $\mathrm{F}(4,28)=20.78^{* * *}$ & \\
Arellano Bond test - Order 1 & $-2.21^{* * *}$ & \\
Arellano Bond test - Order 2 & 0.05 & \\
Hansen-J & chi2(25) $=24.89$ & \\
Dif-Hansen & chi2(13) $=11.29$ & \\
\hline
\end{tabular}

\section{Disentangling the effects of the banking sector and the financial market development levels on private investment in the power sector}

Now that the importance of the financial sector's development in explaining the volume of private investment in developing countries' energy projects is established, let us examine which of the banking sector and capital markets level of development drives these effects. We apply the same estimation methodology as in the previous sections and present results derived from equation (2). Table 13 displays estimation results with bsdev and cmdev as the sole independent variables. Estimates emphasize that the effect of the banking sector's development level on private investment 
is positive though not significant. In contrast, capital markets' development significantly fosters private investment in developing countries' power sector. These findings therefore suggest that the effects of the overall financial sector's development are essentially driven by the level of domestic capital markets’ development.

Table 13

SYS-GMM parameter estimates

\begin{tabular}{ccc}
\hline \hline Variable & Coefficient & Std error \\
\hline lag(privinvt) & $.7491106^{* * *}$ & .0796758 \\
bsdev & 84.48461 & 126.4848 \\
cmdev & $231.4927^{* *}$ & 122.9545 \\
\hline Obs. & 307 & \\
Fisher test & $\mathrm{F}(3,28)=68.96^{* * *}$ & \\
Arellano Bond test - Order 1 & $-2.42^{* * *}$ & \\
Arellano Bond test - Order 2 & -0.05 & \\
Hansen-J & chi2(69) $=22.96$ & \\
Dif-Hansen & chi2(36) $=0.67$ & \\
\hline
\end{tabular}

When institutional and risk factors are added to the model as explanatory variables (Table 14), our findings emphasize that while the banking sector's development surprisingly has adverse, but not significant, effects on private investment, domestic capital markets' development positively and significantly affects private investment in developing countries' power projects. Hence these results lead to the conclusion that the significant positive effects of the overall financial sector development on private investment found in Table 9 can be essentially explained by capital markets' level of development. Moreover, as in Table 9, exchange rate risk seems to be the most important risk factor that may prevent private investors from participating to energy projects’ financing.

Table 14

SYS-GMM parameter estimates

\begin{tabular}{ccc}
\hline Variable & Coefficient & Std error \\
\hline lag(privinvt) & $.6406816^{* * *}$ & .0431686 \\
bsdev & -54.11392 & 48.85219 \\
cmdev & $188.6785^{* * *}$ & 68.38535 \\
exchraterisk & $32.59895^{* * *}$ & 8.212808 \\
\hline Obs. & 306 & \\
Fisher test & $\mathrm{F}(4,28)=105.93^{* * *}$ & \\
Arellano Bond test - Order 1 & $-2.37 * * *$ & \\
Arellano Bond test - Order 2 & -0.08 & \\
Hansen-J & chi2(29) $=23.04$ & \\
Dif-Hansen & chi2(15) $=8.21$ & \\
\hline
\end{tabular}

When controlling for the energy sector regulatory framework (Table 15), capital markets' development still positively and significantly explains the volume of private investment while, 
though the effect is not significant, the latter tends to decrease with the banking sector's development. Our results also show that exchange rate risk has adverse effects on developing countries' energy projects attractiveness to private investors as a high exchange rate risk appears to reduce private investment. These findings therefore confirm our previous results from Table 14 as to the importance of capital markets' development and exchange rate risk for the private sector's investment decisions, and support the conclusion that the positive effects of financial development are driven by the domestic capital markets' development. Furthermore, parameter estimates emphasize that investors are more willing to contribute to energy projects' financing when there exists an independent regulator. Therefore, the domestic energy sector's regulatory framework also matters for private investors.

Table 15

SYS-GMM parameter estimates

\begin{tabular}{ccc}
\hline \hline Variable & Coefficient & Std error \\
\hline lag(privinvt) & $.6151758^{* * *}$ & .0482015 \\
Bsdev & -44.05866 & 51.64461 \\
Cmdev & $185.4939^{* * *}$ & 66.0554 \\
exchraterisk & $17.32381^{* * *}$ & 7.450965 \\
Indepreg & $299.4898^{*}$ & 221.1928 \\
\hline Obs. & 306 & \\
Fisher test & $\mathrm{F}(5,28)=91.01^{* * *}$ & \\
Arellano Bond test - Order 1 & $-2.44^{* * *}$ & \\
Arellano Bond test - Order 2 & -0.05 & \\
Hansen-J & chi2(29) $=25.19$ & \\
Dif-Hansen & chi2(15) $=11.28$ & \\
\hline
\end{tabular}

As the results from section 7 above suggest that overall economic and financial development levels are both key drivers of private investment when considered jointly, we examine in a final step whether the impact of financial sector development can be attributed to a financial sub-sector in particular, i.e., the banking sector or capital markets. Our empirical results displayed in Table 16 confirm the importance of economic growth and capital markets' development in developing countries' attractiveness from private investors' point of view. Indeed, the variables growth and cmdev positively and significantly affect private investment. These findings therefore provide strong evidence that the effects of the financial sector's development on private investments are essentially driven by capital markets' development. When controlling for the regulatory framework in the power sector (Table 17), we find that economic growth and capital markets' development are still significant in explaining private investment. Our empirical results also highlight that the existence of an independent regulator in the energy sector plays an important role in the attractiveness of 
developing countries’ energy projects for private investors.

Table 16

SYS-GMM parameter estimates

\begin{tabular}{ccc}
\hline \hline Variable & Coefficient & Std error \\
\hline lag(privinvt) & $.6671741^{* * *}$ & .0380519 \\
growth & $.5274156^{* *}$ & .2763148 \\
bsdev & .2763148 & 48.84709 \\
cmdev & $157.4972^{* * *}$ & 65.3211 \\
\hline Obs. & 307 & \\
Fisher test & $\mathrm{F}(4,28)=82.99 * * *$ & \\
Arellano Bond test - Order 1 & $-2.40^{* * *}$ & \\
Arellano Bond test - Order 2 & 0.01 & \\
Hansen-J & chi2(29) $=21.73$ & \\
Dif-Hansen & chi2(15) $=5.41$ & \\
\hline
\end{tabular}

Table 17

SYS-GMM parameter estimates

\begin{tabular}{ccc}
\hline \hline Variable & Coefficient & Std error \\
\hline lag(privinvt) & $.6331002^{* * *}$ & .0778513 \\
growth & $.3317886^{*}$ & .2178169 \\
bsdev & -32.67342 & 46.29378 \\
cmdev & $160.1594^{* * *}$ & 65.28836 \\
indepreg & $306.9391^{*}$ & 182.6289 \\
\hline Obs. & 307 & \\
Fisher test & $\mathrm{F}(5,28)=18.41^{* * *}$ & \\
Arellano Bond test - Order 1 & $-2.23^{* * *}$ & \\
Arellano Bond test - Order 2 & 0.01 & \\
Hansen-J & chi2(25) $=23.67$ & \\
Dif-Hansen & chi2(13) $=7.97$ & \\
\hline
\end{tabular}

\section{Conclusion}

This paper has set the objective of empirically investigating the determinants of private investment in developing countries’ power projects, seeking to emphasize the importance of economic growth and financial sector development, using dynamic panel model specifications and accounting for some institutional and risk factors that may influence the private sector’s investment decisions.

Our study of a time-series-cross-sectional data set on 37 developing countries from 1990 to 2007 unambiguously demonstrates that economic growth is a key determinant to private investment in 
power projects, and that private investors also account for countries' governance quality. Our findings also emphasize that the existence of an autonomous energy sector regulator significantly contributes to improving the private sector's involvement in power projects' financing. Likewise, a well developed financial sector, in particular the existence of well established and developed capital market, is found to be a key determinant of private investment in power projects in developing countries. More importantly, our analysis has also shown that a country's exchange rate risk is the most important risk factor that keeps private investors from participating in power projects in developing countries.

Overall, our empirical results suggest that developing countries with a higher economic growth, a more developed financial sector, in particular, capital markets, a better governance and institutional framework attract more private capital for their infrastructure projects. Therefore, in their effort to attract more private investment, policy makers in developing countries should pay particular attention to enhancing the quality of regulation to ensure predictability and certainty while also deepening their domestic financial and capital markets. In a future paper, we will investigate the combined effects of financial and power sectors' reforms on the performance of the power sector with the purpose of testing the hypothesis that financial reforms are a pre-condition to the successful implementation of infrastructure reforms. 


\section{Appendix}

\section{Econometric method}

The data used in this paper is analyzed using a dynamic panel data econometric framework. A general linear dynamic panel-data model has the following form:

$$
y_{i t}=\sum_{j=1}^{p} \alpha_{j} y_{i, t-j}+\mathrm{x}_{i t}^{\prime} \beta_{1}+\mathrm{w}_{i t}^{\prime} \beta_{2}+v_{i}+\varepsilon_{i t}
$$

where $i=1, \ldots, N$ and $t=1, \ldots, T_{i}$ are indices that refer to the country and the year respectively, $y_{i t}$ is a dependent variable, the $\alpha_{j}$ 's are unknown parameters to be estimated, $\mathrm{x}_{i t}$ is $k_{1}$-dimensional vector of strictly exogenous covariates, $\beta_{1}$ is a the vector of corresponding unknown coefficients, $\mathrm{w}_{i t}$ is a $k_{2}$-dimensional vector of predetermined and endogenous covariates, $\beta_{2}$ is the vector of corresponding unknown coefficients, $v_{i}$ are the panel-level effects which may be correlated with the covariates, and $\varepsilon_{i t}$ are error terms which are assumed to be i.i.d. with variance $\sigma_{\varepsilon}{ }^{2}$ and independent from $v_{i}$ for all $i$ and over all $t .^{26}$

This model includes lags of the dependent variable as explanatory variables and unobserved panellevel effects that may be fixed or random. By construction, the lagged dependent variables are correlated with the unobserved panel-level effects, making standard estimation such as within-group estimator inconsistent. As proposed by Arellano-Bond (1991), these panel-level effects are removed by first-differencing the model, yielding:

$$
\Delta y_{i t}=\sum_{j=1}^{p} \alpha_{j} \Delta y_{i, t-j}+\Delta \mathrm{x}_{i t}^{\prime} \beta_{1}+\Delta \mathrm{w}_{i t}^{\prime} \beta_{2}+\Delta \varepsilon_{i t}
$$

Panel-level effects are eliminated but this transformation leads to another endogeneity problem due to the correlation between the transformed lagged dependent variable and the transformed errors. For instance, $\Delta \varepsilon_{i t}=\varepsilon_{i t}-\varepsilon_{i t-1}$ is correlated with $\Delta y_{i, t-1}=y_{i, t}-y_{i, t-1}$ as from equation (A.3) $y_{i, t-1}$ depends

\footnotetext{
${ }^{26}$ Exogenous covariates $x_{i s}$ are orthogonal to $\varepsilon_{i t}$ for all $s$ and $t$ while predetermined covariates $w_{i s}$ are orthogonal to $\varepsilon_{\text {is }}$ only for $s \leq t$, i.e., $E\left(x_{i s} \varepsilon_{i t}\right)=0$ for all $s$ and $t, E\left(w_{i s} \varepsilon_{i t}\right)=0$ for $s \leq t$, and $E\left(w_{i s} \varepsilon_{i t}\right) \neq 0$ for $s>t$.
} 
on $\varepsilon_{i t-1}$.

To obtain consistent estimators for the dynamic panel-data model, Arellano-Bond (1991) proposed to use instruments to form moment conditions and apply GMM techniques developed by Hansen (1982). ${ }^{27}$ Indeed, although the first-differenced errors are correlated with the first-differenced covariates, they may be uncorrelated with certain lagged levels of the covariates. This method requires disturbances to be serially uncorrelated and estimates the model's parameters by identifying how many lags of the dependent variable, the predetermined and endogenous covariates are valid instruments and how these lagged levels can be combined with first differences of the strictly exogenous covariates into a potentially large instrument matrix. Moment conditions are obtained from the first-differenced disturbances from equation (A.4) and instruments. Using this instrument matrix, Arellano and Bond (1991) derive the corresponding one-step and two-step GMM estimators (DIF-GMM). A serial correlation test of the null hypothesis of no serial correlation in the firstdifferenced errors is derived from Arellano-Bond (1991).

However, Arellano and Bond (1991) DIF-GMM estimator may be inconsistent if the autoregressive parameters are too large or the ratio of the variance of the panel-level effects to the variance of idiosyncratic error is too large. Based on their work, Arellano and Bover (1995), Blundell and Bond (1998) developed a system estimator (SYS-GMM) which uses additional moment conditions. Indeed, in addition to the lagged levels used as instruments for the differenced equation (A.4) for the DIF-GMM estimator, SYS-GMM uses lagged first-differenced covariates as instruments for the level equation (A.1). New moment conditions are then derived from the disturbances in equation (A.1) and these additional instruments. This method assumes that there is no autocorrelation in the idiosyncratic errors and requires the initial condition that the panel-level effects be uncorrelated with the first difference of the dependent variable's $1^{\text {st }}$ observation, i.e. $E\left[v_{i} \Delta y_{i 2}\right]=0$ for all $i$. In this paper, we have applied robust one-step SYS-GMM to estimate our models.

\footnotetext{
${ }^{27}$ Note that the Arellano and Bond (1991) estimator is suited for panel data sets with "a large N and a small T".
} 


\section{Variables content and sources of data}

Table A1

Content of variables and data sources

\begin{tabular}{|c|c|c|}
\hline Variable & Content & Source \\
\hline privinvt & $\begin{array}{l}\text { Total private investment in energy projects } \\
\text { (in millions of } 2005 \text { USD). }\end{array}$ & $\begin{array}{l}\text { The World Bank Public-Private } \\
\text { Infrastructure Advisory Facility } \\
\text { database (year). }\end{array}$ \\
\hline gdppercapita & GDP per capita in 2005 USD. & $\begin{array}{l}\text { ERS International Macroeconomic } \\
\text { dataset (2008). }\end{array}$ \\
\hline growth & Growth rate of GDP per capita. & Idem. \\
\hline$C B A$ & $\begin{array}{l}\text { Total assets held by the central bank } \\
\text { expressed as a percentage of GDP. }\end{array}$ & $\begin{array}{lcc}\text { The World Bank } & \text { Financial } \\
\text { Development } & \text { and } & \text { Structure } \\
\text { database (2007). } & & \end{array}$ \\
\hline$D M B A$ & $\begin{array}{l}\text { Total assets held by the financial } \\
\text { institutions expressed as a percentage of } \\
\text { GDP. }\end{array}$ & Idem. \\
\hline CBPC & $\begin{array}{l}\text { Credit granted by commercial banks to the } \\
\text { private sector expressed as a percentage of } \\
\text { GDP. }\end{array}$ & Idem. \\
\hline$S M C$ & $\begin{array}{l}\text { Value of stock market capitalization } \\
\text { expressed as a percentage of GDP. }\end{array}$ & Idem. \\
\hline TVT & $\begin{array}{l}\text { Total value of stocks traded expressed as a } \\
\text { percentage of GDP. }\end{array}$ & Idem. \\
\hline SMT & $\begin{array}{l}\text { Stock market turnover ratio calculated as } \\
\text { the ratio of value of shares traded during a } \\
\text { period to average market capitalization. }\end{array}$ & Idem. \\
\hline countryrisk & $\begin{array}{l}\text { Composite country risk rating reflecting } \\
\text { political, financial, and economic risk } \\
\text { ranging from } 0 \text { to } 100 \text { (the higher the rating } \\
\text { the lower the risk). }\end{array}$ & $\begin{array}{l}\text { International Country Risk Guide } \\
\text { database (year). }\end{array}$ \\
\hline exchraterisk & $\begin{array}{l}\text { Exchange rate risk variable ranging from } 0 \\
\text { to } 10 \text { (the higher the value, the lower the } \\
\text { risk). }\end{array}$ & Idem. \\
\hline corruption & $\begin{array}{l}\text { Corruption index ranging from } 0 \text { to } 6 \text { (the } \\
\text { higher the score, the less corrupt the } \\
\text { economic system). }\end{array}$ & Idem. \\
\hline govtstability & $\begin{array}{l}\text { Variable of the government's ability to stay } \\
\text { in office and carry out its declared } \\
\text { economic program ranging from } 0 \text { to } 12 \\
\text { (the higher the rating, the more stability } \\
\text { there is). }\end{array}$ & Idem. \\
\hline lawandorder & $\begin{array}{l}\text { Index with a "law" component assessing the } \\
\text { strength and impartiality of the legal system } \\
\text { and an "order" component assessing } \\
\text { popular observance of the law. This index } \\
\text { ranges from } 0 \text { to } 6 \text { (the higher the score, the } \\
\text { better the legal environment). }\end{array}$ & Idem. \\
\hline regquality & $\begin{array}{l}\text { Regulatory quality index assessing } \\
\text { perceptions of the ability of the government } \\
\text { private sector development. The score } \\
\text { varies between }-2.5 \text { and }+2.5 \text { (the higher the } \\
\text { score, the better the quality of governance). }\end{array}$ & Kaufmann et al. (2009). \\
\hline indepreg & $\begin{array}{l}\text { Dichotomous variable that takes on the } \\
\text { value } 1 \text { if there exists an energy regulatory } \\
\text { separated from the executive branch of } \\
\text { government and } 0 \text { otherwise. }\end{array}$ & $\begin{array}{l}\text { Cubbin and Stern (2006) and } \\
\text { various websites (see references). }\end{array}$ \\
\hline
\end{tabular}




\section{References}

Arellano, M. and S.R. Bond, 1991, "Some tests of specification for panel data: Monte Carlo evidence and an application to employment equations," Review of Economic Studies, 58: 277-97.

Arellano, M. and O. Bover, 1995, "Another look at the instrumental variable estimation of errorcomponent models," Journal of Econometrics, 68: 29-51.

Asante, Y., 2000, "Determinants of private investment behaviour in Ghana," African Economic Research Consortium Research Paper No. 1000.

Beck, N., and J. Katz, 2004, "Time-series-cross-section issues: Dynamics," Paper presented at the 2004 Annual Meeting of the Society for Political Methodology, Stanford University.

Blundell, R. and S. Bond, 1998, "Initial conditions and moment restrictions in dynamic panel data models," Journal of Econometrics, 87(1): 115-143.

Calitz, E. and J. Fourie, 2007, "Infrastructure in South Africa: Who is to finance and who is to pay?," Stellenbosch Economic Working Paper No. 15/07.

Cubbin, J. and J. Stern, 2006, “The impact of regulatory governance and privatization on electricity industry generation capacity in developing countries”, The World Bank Economic Review Advance Access published March 23, 2006.

ESMAP Study, January 19, 2007, "Latin America and the Caribbean Region (LCR) Energy strategy".

Gasmi, F., Noumba, P., and L. Recuero Virto, 2009, "Political accountability and regulatory performance in infrastructure industries: An empirical analysis," The World Bank Economic Review, 23(3): 509-531.

Gupta, L.C. and C.P. Gupta, 2001, "Financing infrastructure development: A holistic approach with special reference to the power sector”, Society for Capital Market Research \& Development Report, Delhi.

Hansen, L.P., 1982, "Large Sample Properties of Generalized Methods of Moments Estimators" in Econometrica, Vol. 50, page 1029-1054.

Jerome, A.T., 2008, "Private sector participation in infrastructure in Africa," Mimeo, African Peer Review Mechanism Secretariat (APRM).

Kaufmann D., A. Kraay, and M. Mastruzzi, 2009, "Governance Matters VIII: Aggregate and Individual Governance Variables 1996-2008”, World Bank Policy Research Working Paper No. 4978.

Kinda, T., 2008, "Infrastructure and private capital flows in developing countries," Munich Personal 
RePEc Archive Paper No. 19158.

Machungwa, P., 2005, "Paper on Zambia’s experience with power sector reform", Parliamentary reform on energy legislation and sustainable development 5-7 October, 2005, Cape Town, South Africa.

Ministère des finances et de la privatisation, 2005, "Régulation des marches du gaz naturel dans le monde: Enseignements pour le Maroc," Royaume du Maroc.

OECD, 2006, "Promoting private investment for development : The role of ODA," DAC Guidelines and References Series.

Ouattara, B., 2004, "Modelling the long run determinants of private investment in Senegal," Centre for Research in Economic Development and International Trade Research Paper No. 04/05. University of Nottingham.

Pargal, S., 2003, "Regulation and private sector investment in infrastructure: Evidence from Latin America," The World Bank Policy Research No. 3037.

Pineau, P. O., 2004, "Transparency in the Dark - An Assessment of the Cameroonian Electricity Sector Reform".

Platz, D., 2009, "Infrastructure finance in developing countries: The potential of sub-sovereign bonds," Department of Economic and Social Affairs Working Paper No. 76. The United Nations.

Prud'homme, R., 2004, "Infrastructure and development," Paper presented at the Annual World Bank Conference on Development Economics, Washington, DC, May, 3-5, 2004.

RTE, 2006, "Le secteur électrique méditerranéen".

Saidi, N., 2006, "Infrastructure: Key to economic and financial development in MENA," Mimeo, International Financial Centre Authority, Dubai.

Sheppard, R., 2006, "Financing of private infrastructure in Sub-Saharan Africa," Mimeo, PublicPrivate Infrastructure Advisory Facility.

Sheppard, R., von Klaudy, S. and G. Kumar, 2006, "Financing infrastructure in Africa," PublicPrivate Infrastructure Advisory Facility Gridlines Note No. 13.

Straub, S., 2008, "Infrastructure and growth in developing countries: Recent advances and research challenges," World Bank Policy Research Working Paper WPS4460.

The World Bank, 1994, "Infrastructure for development," World Development Report, Oxford University Press.

, 2006, "Private participation in infrastructure: Lessons learned," Paper presented at the OECD Global Forum for International Investment, Istanbul, November 6-7. 
Yepes, T., 2008, "Investment needs in developing countries 2008-15," World Bank’s ETW and LCSSD departments paper.

Zhang, Y., Parker, D., and C. Kirkpatrick, 2004, "Competition, regulation, and privatization of electricity generation in developing countries: Does the sequencing of the reforms matter?"

Zerfu, D., 2001, "Determinants of private investment in Ethiopia," Addis Abeba University.

Websites:

Zimbabwe Electricity Regulatory Commission (ZERC): www.zerc.co.zw/about.html

Bangladesh Energy Regulatory Commission: www.berc.org.bd/

Autorité Nationale de Régulation du Secteur de l'Electricité de Côte d'Ivoire: www.anare.ci

Egyptian Electric Utility \& Consumer Protection Regulatory Agency: www.egyptera.com

China State electricity regulatory Commission: www.serc.gov.cn

Moldova National Energy Regulatory Agency: www.anre.md

Sri Lanka Public Utilities Commission: www.pucsl.gov.lk

Turkey Energy Markets Regulatory Agency: www.epdk.gov.tr/english/default.asp

Ukraine National Electricity Regulatory Commission (NERC): www.nerc.gov.ua 